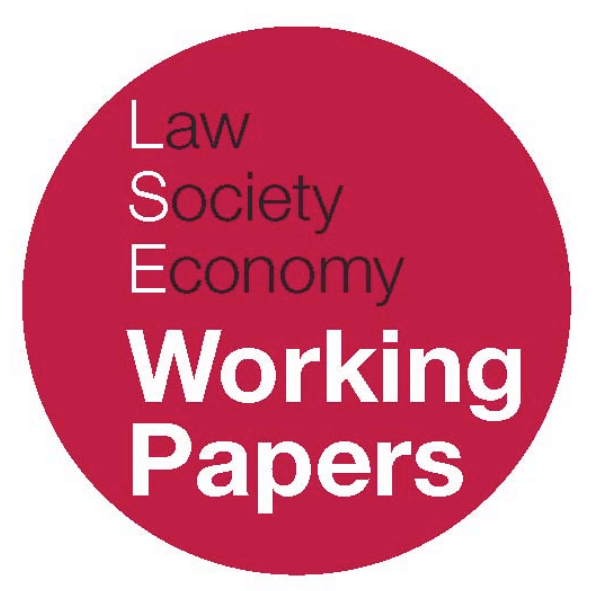

\title{
The Impact of the Human Rights Act on the House of Lords
}

Sangeeta Shah and Thomas Poole

LSE Law, Society and Economy Working Papers 8/2009

London School of Economics and Political Science

Law Department

This paper can be downloaded without charge from LSE Law, Society and Economy Working Papers at: www.lse.ac.uk/collections/law/wps/wps.htm and the Social Sciences Research Network electronic library at: http://ssrn.com/abstract $=1344805$.

(C) Sangeeta Shah and Thomas Poole. Users may download and/or print one copy to facilitate their private study or for non-commercial research. Users may not engage in further distribution of this material or use it for any profit-making activities or any other form of commercial gain. 


\title{
The Impact of the Human Rights Act on the House of Lords
}

\author{
Sangeeta Shah ${ }^{*}$ and Thomas Poole
}

\begin{abstract}
This article examines the impact of the Human Rights Act on the House of Lords. The HRA came into force on 2 October 2000 and has received much attention from academics, lawyers, politicians and members of the public. But there has been little sustained empirical analysis of its impact. This article, the first of a projected series, aims to start redressing this gap. It presents the findings of a quantitative analysis of the judicial caseload of the House of Lords for the period 1994-2007. It also seeks to contribute to the growing literature on the identity and function of the House of Lords (soon to become the Supreme Court).
\end{abstract}

\section{DEBATING THE HUMAN RIGHTS ACT}

The literature on the Human Rights Act ('HRA') is voluminous. Constitutional scholars have analysed the doctrinal developments that have arisen from the cases and made normative claims about the role of the courts in the new legal framework instigated by the Act. These normative claims are often based on or supported by empirical assumptions, assumptions which have not yet been tested systematically. Evidence for these positions tends to be drawn primarily from selected cases and related academic commentary.

\footnotetext{
* School of Law, University of Nottingham.

† Law Department, London School of Economics and Political Science. The authors would like to thank Mark Aronson, David Fraser, Conor Gearty, Bert Huang, Nico Krisch, Mark Lehain, Martin Loughlin, Andrew Lynch and Vanessa Munro for their comments on earlier drafts. We would like to thank Wendy Bremang, Anna Medvinskaia and John Picton for their valuable research assistance. We would also like to acknowledge both the British Academy and the London School of Economics, whose funding made the project of which this article forms a part viable.
} 
These normative positions vary quite widely. Some commentators are measured in their assessment of the impact of the HRA, arguing that the Act has had a perceptible but not necessarily radical impact on judicial decision-making. Gearty, for instance, has argued that 'the majority of decisions [taken under the HRA] have been conservative, rejecting human rights arguments outright or incorporating them with such seamlessness into the pre-existing law that it has been hard to tell whether they have made any difference to the overall result.' ${ }^{1}$ Feldman is equally sanguine. The HRA, he says, "will change constitutional assumptions and values only if it is applied in way which secures continuity with previous constitutional fundamentals'. ${ }^{2}$ Leigh and Masterman conclude their study of the HRA's first decade by observing the 'institutional modesty' with which the Act has been applied, praising the senior judiciary (but not the politicians) for the 'maturity and sensitivity' they have displayed in working their way through the new structure. ${ }^{3}$ Others make more forthright claims. Jowell has argued that the HRA amounts to a 'constitutional departure'. Its introduction ushered in a 'new democratic order', he says, in which the Act operates as 'a higher-order framework, a constitutional order, which constrains all public institutions and is expected to constrain even the legislature itself.' ${ }^{4}$ Others, at the other end of the spectrum, are far more circumspect. Ewing sees the same old story of excessive judicial deference to the executive being repeated in the HRA era. 'While it is true that the HRA has allowed a wider range of questions to be asked before the courts, by applying the same deference that affected the approach to statutory interpretation and judicial review in earlier cases, the answer remains the same: it simply takes more words to produce and more time to read. ${ }^{5}$ Allan, while recognising that the HRA may involve an enhanced role for judges in protecting civil liberties, focuses on the 'more important truth' that 'the new arrangements serve to emphasize the dual sovereignty [of Parliament and the courts] that previously existed.' 6

It is not just academics who have taken a stance on the impact of the HRA politicians and journalists have been equally vocal. The early years of the Act were

${ }^{1}$ C. Gearty, Principles of Human Rights Adjudication (Oxford: Oxford University Press, 2003) 205-6.

2 D. Feldman, 'The Human Rights Act 1998 and Constitutional Principles' (1999) 19 LS 165, 173. See also N. Whitty, T. Murphy and S. Livingstone, Civil Liberties in the Human Rights Act Era (London: Butterworths, 2001) 5: 'The HRA cannot ... be said unequivocally to represent an obvious abandonment of previous constitutional fundamentals'.

${ }^{3}$ I. Leigh and R. Masterman, Making Rights Real: The Human Rights Act in its First Decade (Oxford: Hart, 2008) 293.

${ }^{4}$ J. Jowell, 'Judicial Deference and Human Rights: A Question of Competence' in P. Craig and R. Rawlings (eds), Law and Administration in Europe (Oxford: Oxford University Press, 2003). See also A. Lester, 'The Utility of the Human Rights Act: A Reply to Keith Ewing' [2005] PL 249, 258: 'courts have generally demonstrated their ability in interpreting and applying the broad, open-textured text of the Convention and in weaving the Convention rights into the fabric of our written and unwritten law. They have developed new principles of public law and ensured that individual rights are fairly balanced with community interests.'

5 K.D. Ewing, 'The Futility of the Human Rights Act' [2004] PL 829, 843. See also K. Ewing and J. Tham, 'The Continuing Futility of the Human Rights Act' [2008] PL 668.

6 T.R.S. Allan, Constitutional Justice: A Liberal Theory of the Rule of Law (Oxford: Oxford University Press, 2001) 226. 
accompanied 'by a surprising lack of interest on the part of parliamentarians'.7 Since then, successive Home Secretaries have been critical of how the HRA has been used by judges. ${ }^{8}$ The former Prime Minister also expressed concerns about the operation of the HRA: 'We will need to look again at whether primary legislation is needed to address the issue of court rulings which overrule Government in a way that is inconsistent with other EU countries' interpretation of the European Convention on Human Rights.' The current Justice Secretary, Jack Straw - who, as Home Secretary, was responsible for introducing the HRA recently announced his 'great frustration' with the way the Act had been interpreted by the courts and promised to publish plans to 'rebalance' the legislation with new 'responsibilities' to obey the law and be loyal to the country. ${ }^{10}$ Indeed, the Premiership of Gordon Brown has brought with it more discussion of constitutional amendment, including a plan towards replacing the HRA with a 'British Bill of Rights and Duties'. ${ }^{11}$ Other members of the government have taken a more favourable view. In a government report on the implementation of the HRA the former Lord Chancellor, Lord Falconer, stated: 'The impact of the Human Rights Act upon the development of UK law has been significantly less, and significantly less negative, than some predictions made for it from 1997 onwards. ${ }^{12}$ For the press, The Sun, Britain's bestselling newspaper, launched a campaign to repeal the HRA in light of 'judges' barmy rulings where a criminal's so-called rights come ahead of their victim's', ${ }^{13}$ and the Editor of the Daily Mail commented before the House of Lords Constitution Committee: 'the Human Rights Act is placing judges in a position where they are making more and more contentious decisions which fly in the face of views of politicians and the general populace, $\ldots$ the demand for judges to be accountable is going to grow'. ${ }^{14}$

The debate over the impact of the HRA is vibrant, then, and multidimensional. But it has lacked a sufficiently rigorous empirical dimension. Normative positions and claims are underpinned in part by assumptions about the way the HRA is currently being applied by the courts. But these assumptions have yet to be measured against systematic empirical data. This is not to say that there has been no such analysis. Klug's three 'snapshots' of the operation of the HRA in

\footnotetext{
${ }^{7}$ R. Stevens, The English Judges: Their Role in the Changing Constitution (Oxford: Hart Publishing, 2005) 113.

8 See A.W. Bradley, 'Judicial Independence Under Attack', [2003] PL 397; 'Rein in the Judges Says Blunkett', Telegraph, 9 November 2001; 'Blunkett Fury as Judge Says Lorry Asylum Fines are Illegal', The Times, 6 December 2001. Note that Blunkett's criticism did not stop when he left the government. He has regularly criticised the judiciary in his column in The Sun; for a recent example see 'Judges are Law Unto Themselves', The Sun, 29 April 2008. Charles Clarke, similarly, was rather critical of the judiciary: 'One of the consequences of the Human Rights Act is that our most senior judiciary are taking decisions of deep concern to the security of our society without any responsibility for that security' ('Clarke Blames Judges for Confusion on Rights', Guardian, 4 July 2006).

${ }_{9}^{9}$ See 'Blair Stung into Review of Human Rights Law', Telegraph, 15 May 2006.

10 'Jack Straw reveals: why I want to change the law', Daily Mail, 8 December 2008.

11 The Governance of Britain (Cm 7170, July 2007) 60-63. See also D. Cameron MP, 'Balancing Freedom and Security - A Modern British Bill of Rights', Speech to the Centre of Policy Studies, 26 June 2006.

${ }^{12}$ Department of Constitutional Affairs, 'Review of the Implementation of the Human Rights Act', DCA $38 / 06$ (July 2006) at 3.

13 'Leader', The Sun, 15 May 2006.

${ }^{14}$ House of Lords Constitution Committee Minutes, 7 March 2007.
} 
its early years provided analyses of some of the cases, but was not systematic (and in any case now not up to date). ${ }^{15}$ Nicol's analysis from roughly the same period concentrates on the political and Parliamentary dimensions of the HRA, ${ }^{16}$ whereas Sunkin's study of the effect of the HRA on the incidence of litigation against public bodies covered only the first 5 months of the Act's operation. ${ }^{17}$ A more recent study of decision-making in the House of Lords by Dickson is more relevant, but neither systematic nor quantitative. ${ }^{18}$ Many of the more significant studies have been published outside the law journals. Goold, Lazarus and Swiney compiled a comparative survey of the HRA for the Ministry of Justice, covering the ECHR, Germany, France and Spain in addition to the UK, but which only focussed on proportionality and the issue of 'balancing' rights and security. ${ }^{19}$ Raine and Walker studied the early effects of the HRA for the Lord Chancellor's Department. However, their report - which dealt with the period 2000-02 - is outdated..$^{20}$ Equally, the Public Law Project's study of the impact of the HRA, ${ }^{21}$ while certainly systematic, is limited to the study only of judicial review applications over a 6-month period in 2002.22 And the Department of Constitutional Affairs' own review of the implementation of the HRA adopts a case study (non-quantitative) approach which is neither comprehensive nor systematic. ${ }^{23}$

There are many reasons for thinking that a rigorous empirical analysis of the judicial caseload in the period preceding and postdating the introduction of the HRA might be particularly valuable at this juncture. The HRA is now in its 'adolescent stage', neither entirely young nor yet fully mature. Detailed case studies of the type that pervade the debate on the HRA should be supplemented with

${ }^{15}$ F. Klug and K. Starmer, 'Incorporation Through the "Front Door": The First Year of the Human Rights Act' [2001] PL 654; F. Klug and C. O'Brien, 'The First Two Years of the Human Rights Act' [2002] PL 649; F. Klug and K. Starmer, 'Standing Back from the Human Rights Act: How Effective is it Five Years On?' [2005] PL 716.

${ }^{16}$ D. Nicol, 'The Human Rights Act and the Politicians' (2004) 24 Legal Studies 451. See also J. Hiebert, and J.L. Hiebert, 'Parliamentary Bills of Rights: An Alternative Model?' (2006) 69 MLR 7; C. Evans and S. Evans, 'Evaluating the Human Rights Performance of Legislatures' (2006) 6 Human Rights Law Review 545. 17 M. Sunkin, 'Trends in Judicial Review and the Human Rights Act' (2001) 21 Public Money and Management 9

${ }^{18}$ B. Dickson, 'Safe in Their Hands? Britain's Law Lords and Human Rights' (2006) 26 Legal Studies 329.

${ }^{19}$ B. Goold, L. Lazarus and G. Swiney, 'Public Protection, Proportionality and the Search for Balance' (Ministry of Justice Research Series 10/07, September 2007)

${ }^{20} \mathrm{~J}$. Raine and C. Walker, 'The Impact on Courts and the Administration of Justice of the Human Rights Act 1998' (Lord Chancellor's Department Research Series 9/02, 2002); also published in S. Halliday and P. Schmidt (eds), Human Rights Brought Home: Socio-Legal Perspectives on Human Rights in the National Legal Context (Oxford: Hart Publishing, 2004).

${ }^{21}$ Public Law Project, 'The Impact of the Human Rights Act on Judicial Review: An Empirical Research Study' (June 2003).

22 A recent Ministry of Justice report deals with the implementation of the HRA in government and public administration: 'Human Rights Insight Project' (Ministry of Justice Research Series 1/08, January 2008). A study in Scotland looks specifically at the Scottish courts: P. Greenhill, T. Mullen, J. Murdoch, S. Craig, A. Miller and F. MacDonald, 'The Use of Human Rights Legislation in Scottish Courts' (Scottish Executive: Research Findings No. 54/2004)

${ }^{23}$ Department of Constitutional Affairs, $\mathrm{n} 12$ above. 
quantitative evidence of a systematic nature. 'Anecdote will no longer do.'24 Scholars and other commentators are not in a position to make assumptions about how the courts are using the Act on the basis of how 'things have always been done'. At the same time, there has been sufficient practice to allow us to identify with reasonable confidence the trends that might arise from the analysis. In this respect, we have an advantage over earlier empirical studies of the Act.

The House of Lords is a worthy object of inquiry. Highest courts are regularly the subject of empirical analysis in other jurisdictions. The Harvard Law Review has a tradition dating back to the 1920s of including statistical tables on the annual practices of the US Supreme Court. ${ }^{25}$ More generally, quantitative analysis of judges and judging is currently a vibrant strand of legal (and political science) scholarship, as a slew of prominent new works attest. ${ }^{26}$ The decisions of the High Court of Australia have been subject to jurimetric analysis in recent years. ${ }^{27}$ The Supreme Court of Canada has received similar attention, ${ }^{28}$ as has the German Federal Supreme Court. ${ }^{29}$ There has been relatively little empirical work into the House of Lords, ${ }^{30}$ however, and that work has not been primarily quantitative ${ }^{31}$ nor addressed to the field of human rights.

24 S. Choudhry and C.E. Hunter, 'Measuring Judicial Activism on the Supreme Court of Canada: A Comment on Newfoundland (Treasury Board) v NAPE' (2003) 58 McGill Law Journal 525, 530.

${ }^{25}$ For discussion see 'The Supreme Court, 1960 Term' (1961) 75 Harvard Law Review 40, 84-92.

26 See, e.g., R.A. Posner, How Judges Think (Camgridge, MA: Harvard University Press, 2008); C.R. Sunstein, D. Schkade, L.M. Ellmann and A. Sawicki, Are Judges Political? An Empirical Analysis of the Federal Judiciary (Brookings Institutional Press, 2006); L. Epstein and J.A. Segal, Advice and Consent: The Politics of Judicial Appointments (Oxford: Oxford University Press, 2005); J.A. Segal and H.J. Spaeth, The Supreme Court and the Attitudinal Model (Cambridge: Cambridge University Press, 1993).

${ }^{27}$ See, e.g., A. Lynch, 'The Gleeson Court on Constitutional Law: An Empirical Analysis of its First Five Years' (2003) 26 University of New South W ales Law Journal 32; Lynch, 'Does the High Court Disagree More Often in Constitutional Cases? A Statistical Study of Judgment Delivery 1981-2003' (2005) 33 Federal Law Review 485; R. Smyth, 'The Role of Attitudinal, Institutional and Environmental Factors in Explaining Variations in the Dissent Rate on the High Court of Australia' (2005) 40 Australian Journal of Political Science 519. See also C. Evans and S. Evans, 'Evaluating the Human Rights Performance of Legislatures' (2006) 6 Human Rights Law Review 545.

28 A.D. Heard, 'The Charter in the Supreme Court of Canada: The Importance of Which Judges Hear an Appeal' (1991) 24 Canadian Journal of Political Science 289; F.L. Morton, P.H. Russell and M.J. Withey, 'The Supreme Court's First One Hundred Charter of Rights Decisions: A Statistical Analysis' (1992) 30 Osgoode Hall Law Journal 1; J.B. Kelly, 'The Charter of Rights and Freedoms and the Rebalancing of Liberal Constitutionalism in Canada, 1982-1997' (1999) 37 Osgoode Hall Law Journal 625; Choudhry and Hunter, n 24 above. See also R. Hirschl, Towards Juristocracy: The Origins and Consequences of the New Constitutionalism (Cambridge, MA: Harvard University Press, 2007), which draws on empirical investigations of supreme (or constitutional) courts in Canada, Israel, New Zealand and South Africa.

${ }^{29}$ M. Siems, 'The Adjudication of the German Federal Supreme Court (BGH) in the Last 55 Years - A Quantitative and Comparative Approach' (2007) Oxford University Comparative Law Forum 4 at http://ouclf.iuscomp.org/.

${ }^{30}$ See, e.g., K. Blom-Cooper and G. Drewry, Final Appeal: A Study of the House of Lords in its Judicial Capacity (Oxford: Oxford University Press, 1972); A. Paterson, The Law Lords (London: Macmillan, 1982); B. Dickson, 'The Processing of Appeals in the House of Lords' (2007) 123 Law Quarterly Review 571; B. Dickson, 'The Lords of Appeal and their Work 1967-96' in B. Dickson and P. Carmichael (eds), The House of Lords: Its Parliamentary and Judicial Roles (Oxford: Hart Publishing, 1999). For similar analysis outside the House of Lords see, e.g., R. Munday, “All for One and One for All' The Rise to Prominence of the Composite Judgment within the Civil Division of the Court of Appeal' (2002) 61 Cambridge Law Journal 321; Munday, 'Judicial Configurations: Permutations of the Court and Properties of Judgment' (2002) 61 Cambridge Law Journal 612; G. Drewry, L. Blom-Cooper and C. Blake, The Court of Appeal (Oxford: Hart Publishing, 2007). 
Our research, since it examines only the House of Lords, cannot provide a comprehensive account of the impact of the HRA on the courts. The task of assessing the caseload of all courts in England and Wales, Scotland and Northern Ireland is beyond the scope of the present study. Examining cases at one level is a manageable starting point and, as it has been suggested that 'the highest density of HRA cases is in the House of Lords', ${ }^{32}$ our analysis should provide valuable insights. Moreover, the House of Lords, soon to become the Supreme Court, ${ }^{33}$ is undergoing a process of major restructuring. Some commentators have suggested that the House of Lords has begun to refashion itself within the HRA framework as something approaching a constitutional or supreme court. ${ }^{34}$ The present study also casts light upon the nature and scope of this development.

Our analysis provides additional data on which participants in these debates might draw. But there are limitations to this particular genre. The consistent application of a reasonably rigid methodology, the essence of statistical analysis of this sort, can present important information but not the whole picture. In particular, the quantitative method treats all decisions as having equal importance when in fact the significance of each decision varies. (Think, for instance, of the disproportionate significance of the Belmarsh case in the survey period. ${ }^{35}$ ) It is important not to fall headlong into the 'reductionist trap' by privileging 'variables that can be measured with relative ease from the entire set' of House of Lords cases. ${ }^{36}$ Although statistical analysis can ultimately do no more than 'provide a factual foundation on which other studies can build, qualify and elaborate, ${ }^{37}$ some tentative conclusions will be drawn from the analysis.

\section{THE STUDY}

Four avenues of research were selected. Grants of leave to appeal were examined first. Leave to appeal can be granted either by a lower court (now rare in civil cases $^{38}$ ) or by an Appeal Committee of the House of Lords ${ }^{39}$ in cases which raise

\footnotetext{
${ }^{31}$ But see, e.g., D. Robertson, 'Judicial Ideology in the House of Lords: A Jurimetric Analysis' (1982) 12 British Journal of Political Science 1.

32 Department of Constitutional Affairs, n 12 above, 10.

${ }^{33}$ Constitutional Reform Act 2005, Pt 3. See also A.P. Le Sueur (ed), Building the UK's New Supreme Court (Oxford: Oxford University Press, 2004).

${ }^{34}$ D. Nicol, 'Law and Politics After the Human Rights Act' [2006] PL 722, 743: 'the Law Lords have shown ideological unity during the early years of the HRA. It is therefore not entirely fanciful to recast the Law Lords as a political faction.'

35 A v Secretary of State for the Home Department [2004] UKHL 56. For commentary, see, e.g., S. Shah, 'The U.K.'s Anti-Terror Legislation and the House of Lords: The First Skirmish' (2005) 5 HRLR 403.

${ }^{36}$ Choudhry and Hunter, n 24 above, 534.

37 Morton, Russell and Riddell, n 28 above, 2.

38 See, e.g., C. Blake and G. Drewry, 'The Role of the Court of Appeal in England and Wales as an Intermediate Court', in Le Sueur, n 33 above, 221-235.

39 An Appeal Committee is composed of three Law Lords. Decisions are usually based on the documentation entered by the petitioner in support of their application but in certain circumstances
} 
'a point of law of general importance'. 40 The aim was to test for any increased willingness on the part of the Law Lords to hear appeals that raised human rights issues. Second, the judgments handed down during the sample period were tested for the incidence of human rights arguments. Third, the 'win rate' of these human rights arguments was assessed. Finding out how frequently human rights arguments met with success provides an indication of the substance of decisionmaking and thus of the HRA's real impact. Finally the caseload of the Privy Council was examined in a similar way in order to elicit a more complete picture of the activities of the institution that will soon become the Supreme Court.

\section{LEAVE TO APPEAL}

A database of petitions for leave to appeal to the House of Lords was compiled for the period 1 January 1994 to 31 December 2007. Compiling a dataset that included the six year period before the HRA came into force as well as the seven years that followed allows for the drawing of fairly robust conclusions. The data was drawn from the Minutes of Proceedings of the House of Lords. The Minutes record all decisions of the Appeal Committees that determine whether leave to appeal is to be granted. ${ }^{41}$ Our analysis records all applications for leave to appeal in the sample period, as well as the Appeal Committees' decisions. Applications for leave to appeal are normally made by individual petitions, even when a case was heard at the lower level alongside others. This pattern is reflected in our statistics, which count each individual petition for leave.

The official Judicial Statistics were not used in this study. The Statistics are produced each year and analyse the work of Appeal Committees. But inconsistencies in these data have been noted; 42 these can be avoided by drawing directly on the original records. This means, of course, that there are some differences between our figures and those of the official Statistics.

\footnotetext{
respondents may be invited to provide written objections setting out their views on whether leave should be given and if this is not persuasive an oral hearing may be convened. In recent times two Appeal Committees have been convened to process petitions for leave to appeal.

40 'There is a multitude of reasons why, in a particular case, leave to appeal may be refused by an appeal committee. I shall not attempt to embark upon an exhaustive list for it would be impossible to do so. One reason may be that the particular case raises no question of general principle but turns upon its own facts. Another may be that the facts of the particular case are not suitable as a foundation for determining some question of general principle. Your Lordships' House is only able, in any given year, to hear and determine a limited number of cases and it is important for the evolution of the law as a whole that those cases should be carefully chosen': In re Wilson [1985] 2 W.L.R. 694,756 .

41 Minutes from June 1998 are published online at: http://www.parliament.the-stationeryoffice.co.uk/pa/ld/ldminar.htm; for minutes prior to this Bound Volumes of Minutes held at the Parliamentary Archives were consulted.

42 See, for example, B. Dickson, 'The Lords of Appeal and their Work 1967-96' in B. Dickson and P. Carmichael, The House of Lords Its Parliamentary and Judicial Roles (Oxford: Hart Publishing, 1999) 140.
} 
Figure 1: Outcome of Petitions for Leave to Appeal

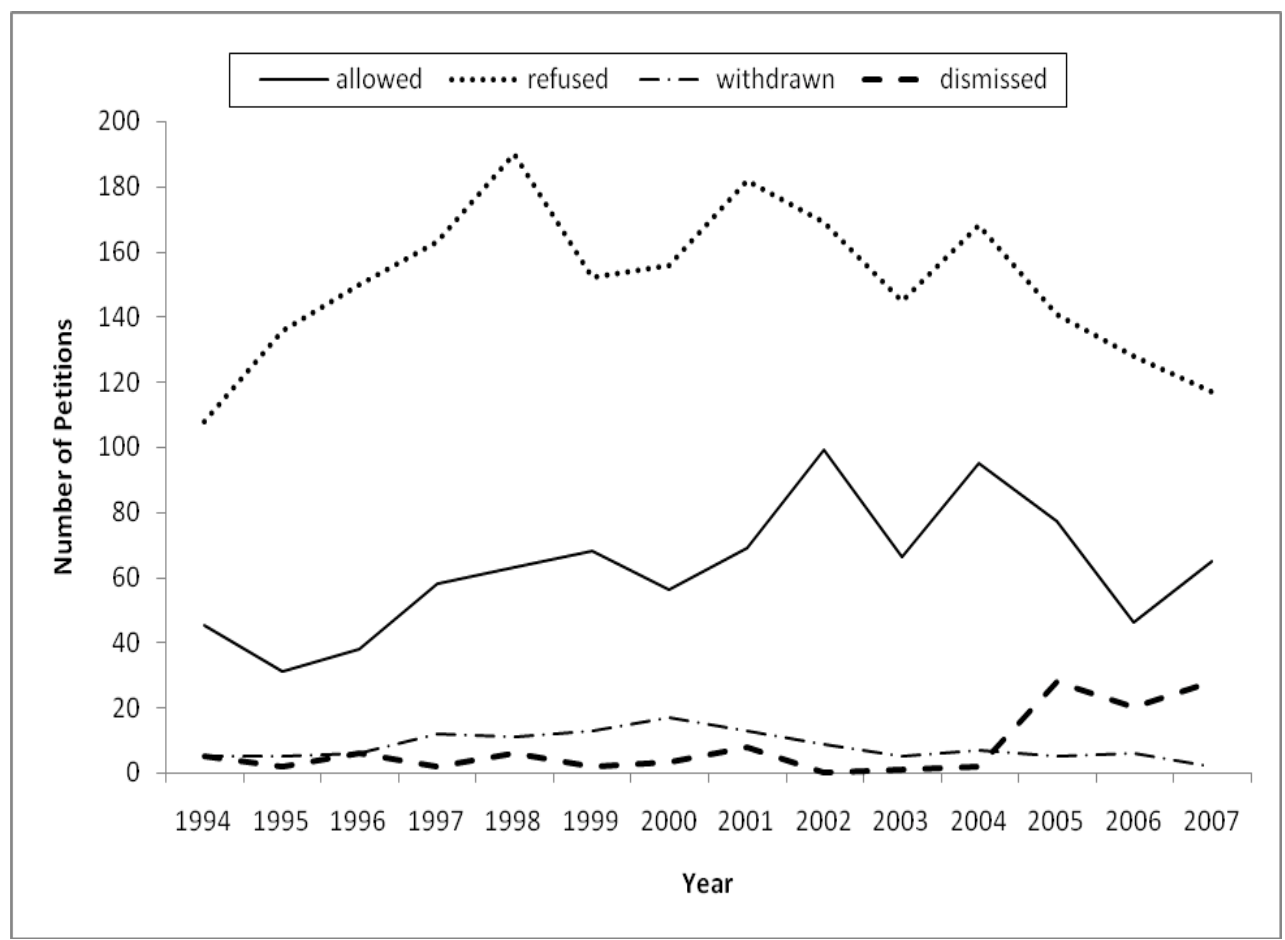

Figure 1 reproduces graphically the data on the outcomes of petitions for leave to appeal. One general observation is that the number of petitions for leave to appeal has risen during the sample period. The total number of petitions entered in 1994 was 163 . This rose steadily to a peak of 277 petitions in 2002. By the end of the sample period (2007) the number had decreased to 212. Despite this overall increase, the success rate of petitions has remained fairly constant during the period, with around 1 in 3 being granted leave to appeal. More pertinently for the purposes of the present inquiry, there was no substantial increase in the general success rate of petitions after the HRA came into force.

The subject matter of the petitions was examined next. Disregarding at this point petitions held inadmissible or withdrawn before a decision on leave could be taken, each petition was traced back to the lower court decision that prompted it and coded according to its subject matter. We used the following case classification: (a) human rights; (b) rights-related; (c) refugee; and (d) other.

These categories need some explanation. For the purposes of the study a 'human rights case' was one that involved discussion of a right protected by the HRA, an international human rights treaty (excluding cases concerning refugees which was given its own category - see below) such as the United Nations Convention Against Torture 198443 or the European Convention on Human

${ }^{43}$ See, e.g., $A$ and others v Secretary of State for the Home Department [2005] 1 WLR 414. 
Rights 1950 ('ECHR'), ${ }^{44}$ or customary international human rights law. Cases were included in this category if the right was discussed by at least one judge. The category also includes cases where a rights issue was raised in argument but not mentioned in any judgment. ${ }^{45}$ It also includes those cases in which the human rights issue was only a minor point or incidental to the central questions in the case. So, where the rights issue was only one question among many, ${ }^{46}$ or only addressed in one judge's opinion, the case was classified as a human rights case.

The 'rights-related' category refers in this context to cases that raise civil liberties or equality issues in which there was no mention of human rights in any of the judgments. We went beyond Gearty's minimalist (and controversial) understanding of civil liberties as 'political freedoms that we must have available to us all if it is to be true to say of us that we live in a society that adheres to the principle of representative, or democratic government 47 to include police powers, ${ }^{48}$ detention, ${ }^{49}$ fair trial ${ }^{50}$ and criminal justice issues. ${ }^{51}$ The 'refugee' category relates to cases concerning the rights and treatment of refugees and asylum seekers in which there was no mention of human rights in the judgments. The catch-all 'others' category includes all those cases that did not fall into the 'human rights', 'rights-related' or 'refugee' categories.

Although the categories are not mutually exclusive, cases were only coded as one type or another. Whenever a case could be coded as both 'human rights' and either 'rights-related' or 'refugee', it was considered to be a 'human rights' case. We recognise that this approach might lead to an over-counting of 'human rights' cases and thus to a possible over-accentuation of the importance of human rights. But our approach is not only a pragmatic solution to an intractable problem, since in practice cases do not fall neatly into pre-arranged categories, but also justified given that our primary concerns relate to the both the incidence of human rights cases as well as the willingness of the House of Lords to hear cases with a human rights element. Given this aim, under-counting rights would be a greater sin than over-counting them.

The results are presented below. Table 1 provides a breakdown of petitions for leave to appeal (excluding those that were withdrawn) made to the House of Lords during the period of study. A preliminary issue to note is that some petitions could not be traced back to the lower court decision since not all such

\footnotetext{
44 See, e.g., the pre-HRA case R v Secretary of State for the Home Department, ex parte Phull, [1996] Imm. AR 72 .

45 In $\mathrm{R}$ (L (A Minor)) v Governors of J School, [2001] EWCA Civ 1199, for instance, counsel for the appellant argued that the terms upon which his reinstatement to school following exclusion would be in violation of his rights to association as protected in Articles 10 and 11. This argument was dismissed without consideration as being "bad" for the reasons given by the lower court.

46 See, e.g., JA Pye (Oxford) Ltd and Another v Graham and Another, [2001] 2 WLR 1293.

47 C. Gearty, Civil Liberties (Oxford: Oxford University Press, 2007), 3. 'Political freedoms' in this context includes inter alia freedom of expression, assembly and association and the right to vote.

48 See, e.g., Cullen v Chief Constable of the Royal Ulster Constabulary [1999] N.I. 237.

49 See, e.g., McGrath v Chief Constable of the Royal Ulster Constabulary [2000] N.I. 56.

50 See, e.g., R v Brown [1994] 1 WLR 1599.

51 See, e.g., R v Johnson (Jason Everton) [2007] EWCA Crim 1651.
} 
decisions are reported. These petitions were recorded as untraceable. They account for no more than $5 \%$ of all petitions made in any given year.

Table 1: Petitions for Leave to Appeal by Type

\begin{tabular}{|c|c|c|c|c|c|c|}
\hline $\begin{array}{l}\text { No of } \\
\text { Petitions } \\
\text { per year }\end{array}$ & $\begin{array}{l}\text { Human } \\
\text { Rights }\end{array}$ & $\begin{array}{l}\text { Rights- } \\
\text { Related }\end{array}$ & Refugee & Others & $\begin{array}{l}\text { Untracea } \\
\text { ble }\end{array}$ & Total \\
\hline 1994 & & & & & & \\
\hline Total & 1 & 23 & 1 & 179 & 5 & 209 \\
\hline Allowed & 1 & 6 & 0 & 57 & 0 & 64 \\
\hline $\begin{array}{r}\text { Refused } \\
1995\end{array}$ & 0 & 17 & 1 & 122 & 5 & 145 \\
\hline Total & 2 & 21 & 2 & 175 & 6 & 206 \\
\hline Allowed & 1 & 5 & 0 & 31 & 0 & 37 \\
\hline $\begin{array}{r}\text { Refused } \\
1996\end{array}$ & 1 & 16 & 2 & 144 & 6 & 169 \\
\hline Total & 5 & 9 & 3 & 160 & 7 & 184 \\
\hline Allowed & 0 & 2 & 0 & 33 & 0 & 35 \\
\hline $\begin{array}{r}\text { Refused } \\
1997\end{array}$ & 5 & 7 & 3 & 127 & 7 & 149 \\
\hline Total & 3 & 23 & 7 & 184 & 5 & 222 \\
\hline Allowed & 2 & 10 & 4 & 43 & 0 & 59 \\
\hline $\begin{array}{r}\text { Refused } \\
1998\end{array}$ & 1 & 13 & 3 & 141 & 5 & 163 \\
\hline Total & 9 & 27 & 6 & 208 & 3 & 253 \\
\hline Allowed & 5 & 11 & 4 & 43 & 0 & 63 \\
\hline $\begin{array}{r}\text { Refused } \\
1999\end{array}$ & 4 & 16 & 2 & 165 & 3 & 190 \\
\hline Total & 13 & 24 & 7 & 173 & 3 & 220 \\
\hline Allowed & 2 & 12 & 2 & 52 & 0 & 68 \\
\hline $\begin{array}{r}\text { Refused } \\
2000\end{array}$ & 11 & 12 & 5 & 121 & 3 & 152 \\
\hline Total & 11 & 16 & 3 & 182 & 0 & 161 \\
\hline Allowed & 10 & 5 & 2 & 39 & 0 & 56 \\
\hline $\begin{array}{r}\text { Refused } \\
2001\end{array}$ & 1 & 11 & 1 & 143 & 0 & 156 \\
\hline Total & 49 & 18 & 4 & 176 & 3 & 250 \\
\hline Allowed & 31 & 4 & 1 & 33 & 0 & 69 \\
\hline $\begin{array}{r}\text { Refused } \\
2002\end{array}$ & 18 & 14 & 3 & 143 & 3 & 181 \\
\hline Total & 60 & 25 & 2 & 178 & 2 & 267 \\
\hline Allowed & 37 & 9 & 1 & 52 & 0 & 99 \\
\hline
\end{tabular}




\begin{tabular}{r|lllrl|l}
\hline Refused & 23 & 16 & 1 & 126 & 2 & 168 \\
$\mathbf{2 0 0 3}$ & & & & & & \\
Total & 50 & 21 & 4 & 134 & 3 & 212 \\
Allowed & 28 & 5 & 0 & 34 & 0 & 67 \\
Refused & 22 & 16 & 4 & 100 & 3 & 145 \\
$\mathbf{2 0 0 4}$ & & & & & & \\
Total & 57 & 22 & 7 & 176 & 0 & 262 \\
Allowed & 25 & 9 & 3 & 57 & 0 & 94 \\
Refused & 32 & 13 & 4 & 119 & 0 & 168 \\
$\mathbf{2 0 0 5}$ & & & & & & \\
Total & 56 & 23 & 3 & 135 & 1 & 218 \\
Allowed & 29 & 8 & 3 & 37 & 0 & 77 \\
Refused & 27 & 15 & 0 & 98 & 1 & 141 \\
2006 & & & & & & \\
Total & 33 & 12 & 2 & 124 & 2 & 173 \\
Allowed & 7 & 3 & 0 & 35 & 0 & 45 \\
Refused & 26 & 9 & 2 & 89 & 2 & 128 \\
2007 & & & & & & \\
Total & 44 & 24 & 0 & 102 & 2 & 172 \\
Allowed & 24 & 5 & 0 & 26 & 0 & 55 \\
Refused & 20 & 19 & 0 & 76 & 2 & 117 \\
\hline
\end{tabular}

Dickson observes in his study of the House of Lords that there appears to be no systematic procedure by which petitions are given leave to appeal. ${ }^{52}$ Nor is there any authoritative elaboration of the only criterion upon which an Appeals Committee decides to grant leave: the presence of 'an arguable point of law of general public importance which ought to be considered by the House at this time'. But a number of pertinent observations can be made. The incidence of human rights petitions increased very substantially after the HRA came into force. 'Rights-related' petitions, by contrast, remained fairly constant over the period. The incidence of other petitions decreased substantially (from an average of 169 petitions per year to one of 147 per year after the introduction of the Act). Unfortunately, the results cannot say definitively to what extent this realignment was due to a surge in 'genuine' new human rights cases or a post-HRA 'repackaging' of claims that would otherwise have been argued on other grounds. They do show, however, that there has been no discernible trend in respect of petitions concerning 'refugee' cases. While the incidence of such cases varies widely across the course of the survey, there is no indication that the introduction of the HRA has led to an increase in petitions for leave to appeal in respect of this category of case.

The data concerning the success rate of different types of petition is revealing. The relevant data is presented graphically in Figure 2. The success rate of human

52 Dickson, 'The Processing of Appeals in the House of Lords', n 30 above, 586-7. 
rights petitions has increased substantially since the HRA came into force. (There was a spike in 2000 , when $91 \%$ of human rights petitions were granted leave. But one might also note the dip in 2006, where the success rate was only $28 \%$.) The success rate for 'rights-related' petitions remained fairly constant over the course of our sample period. Roughly 1 in 3 of such petitions tends to be granted leave. (Although one might note the spike in the three years preceding the introduction of the HRA.) Success rates for other types of case remained fairly constant, with a similar success rate of around 1 in 3 .

Figure 2: Success Rate for Petitions for Leave to Appeal by Type

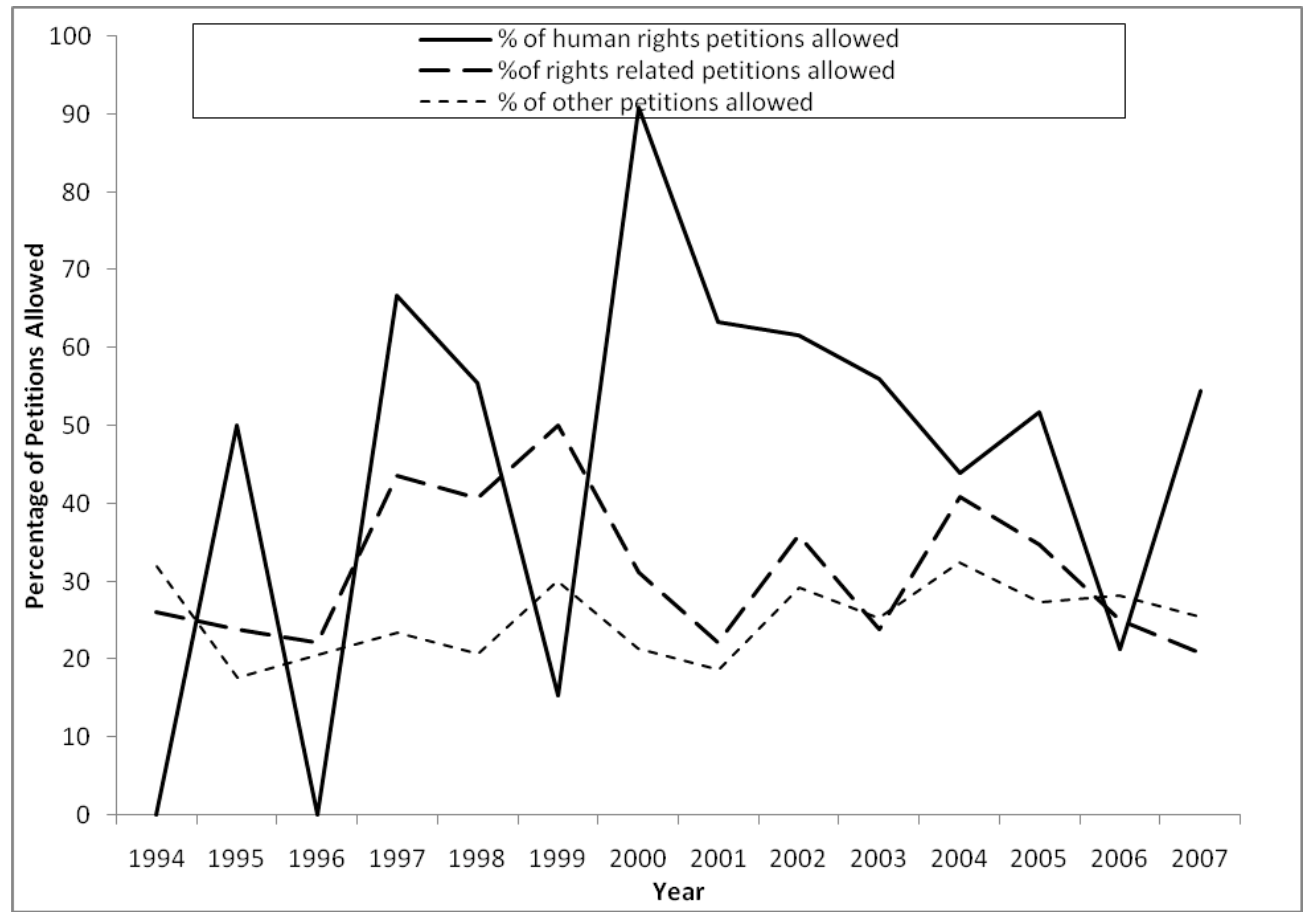

A different way of presenting the data concerning the success of leave to appeal petitions is to use aggregates of successful petitions. By setting the numbers from a pre-HRA period (say, 1996-9) against those from a post-HRA period (say, 2003-6) rounds off any 'spikes' or 'troughs' in the data and can reveal more clearly the changes that have taken place. What we are most interested in here are trends in human rights and rights-related petitions. For the selected periods, as Table 2 reveals, the total number of successful rights-related petitions is somewhat lower in the later period than the earlier (25 in 2003-6 compared with 35 in 1996-9). But there is a very substantial difference in the number of successful human rights petitions - only 9 in 1996-9 compared with 89 in 2003-6. 
Table 2: Success of Petitions for Leave to Appeal-Aggregates

\begin{tabular}{|c|c|c|c|c|}
\hline & Total & & Total & Total \\
\hline & $\begin{array}{l}\text { Number } \\
\text { Successful } \\
\text { Petitions }\end{array}$ & of & $\begin{array}{l}\text { Human Rights } \\
\text { Successes }\end{array}$ & $\begin{array}{l}\text { Rights-Related } \\
\text { Successes }\end{array}$ \\
\hline 1996-1999 & 225 & & 9 & 35 \\
\hline $2003-2006$ & 283 & & 89 & 25 \\
\hline
\end{tabular}

To complete this section of the study, we also coded the appeals to the House of Lords granted by lower courts. ${ }^{53}$ There has been a dramatic decrease in the number of such grants of appeal, ${ }^{54}$ a trend that has left a dataset too small to allow the drawing of any solid conclusions. (Although what this category of case lacks in quantity it makes up for in quality: many of the referrals from lower courts produced seminal HRA cases. ${ }^{55}$ ) In as much as they indicate anything, the trends in these cases match those observed in the petitions for leave (more human rights cases; consistent numbers of rights-related and refugee cases; fewer 'other' cases). The results are presented in Table 3.

Table 3: Appeals Given by Lower Courts by Type

\begin{tabular}{c|cccc}
\hline Year & $\begin{array}{c}\text { Human Rights } \\
\text { appeals }\end{array}$ & $\begin{array}{c}\text { Rights-related } \\
\text { appeals }\end{array}$ & $\begin{array}{c}\text { Refugee } \\
\text { appeals }\end{array}$ & $\begin{array}{c}\text { Other } \\
\text { appeals }\end{array}$ \\
\hline $\mathbf{1 9 9 4}$ & 0 & 1 & 1 & 21 \\
$\mathbf{1 9 9 5}$ & 0 & 1 & 0 & 6 \\
$\mathbf{1 9 9 6}$ & 0 & 0 & 1 & 6 \\
$\mathbf{1 9 9 7}$ & 0 & 1 & 0 & 13 \\
$\mathbf{1 9 9 8}$ & 2 & 2 & 2 & 9 \\
$\mathbf{1 9 9 9}$ & 3 & 1 & 1 & 7 \\
\hline
\end{tabular}

${ }^{53}$ Leave to appeal to the House of Lords may be granted by the Court of Appeal, the High Court, the Court of Appeal of Northern Ireland and the Court Martial Appeal Court. Judgments from the Court of Session can be appealed to the House of Lords without leave being granted by either court, unless the decision being appealed is an interlocutory judgment which displays no difference of opinion between the judges of the Court of Session, or the claim is dismissed on a preliminary issue and the merits are not heard. This being so, appeals coming directly from the Court of Session, without leave being granted, were not considered in the study.

54 Blom-Cooper and Drewry found that for the period between 1952 and 1968, approximately 61\% of appeals to the House of Lords were granted leave by a lower court: Final Appeal, n 30 above, 131-132. Dickson discovered that the figure has dropped to around 12\% for the period 2003-2005 and argued that 'lower courts have grown increasingly reluctant to grant leave to appeal': see Dickson, 'The Processing of Appeals in the House of Lords', $\mathrm{n} 30$ above, 572.

${ }^{55}$ E.g., $R$ v A (No. 2) [2002] 1 AC 45; R v Kansal [2001] UKHL 62; Attorney-General's Reference No. 2 of 2001 [2003] UKHL 68; R (on the application of Saadi) v Secretary of State for the Home Department [2002] UKHL 41; Matthens v Ministry of Defence [2003] UKHL 4; R v Her Majesty's Coroner for the County of West Yorkshire, ex parte Sacker [2004] UKHL 11; R v Special Adjudicator, ex p Ullah [2004] UKHL 26; R (on the application of Limbuela) v Secretary of State for the Home Department [2005] UKHL 66; Jones v Ministry of Interior for Kingdom of Saudi Arabia [2006] UKHL 26; Al-Skeini [2007] UKHL 26; Al Jeddah [2007] UKHL 58; YL v Birmingham City Council [2007] UKHL 27. 


\begin{tabular}{l|llll}
\hline $\mathbf{2 0 0 0}$ & 1 & 0 & 0 & 6 \\
$\mathbf{2 0 0 1}$ & 3 & 0 & 0 & 4 \\
$\mathbf{2 0 0 2}$ & 5 & 1 & 1 & 2 \\
$\mathbf{2 0 0 3}$ & 6 & 1 & 2 & 2 \\
$\mathbf{2 0 0 4}$ & 3 & 1 & 0 & 3 \\
$\mathbf{2 0 0 5}$ & 6 & 1 & 0 & 2 \\
$\mathbf{2 0 0 6}$ & 1 & 0 & 1 & 5 \\
$\mathbf{2 0 0 7}$ & 2 & 0 & 0 & 4 \\
\hline
\end{tabular}

So what does this study of the 'threshold' dimension of the House of Lords' business reveal? The numbers of petitions received annually by the House of Lords have gone up slightly during the sample period. Since there has been no change in the general success rate of leave petitions, the House of Lords has become a slightly busier court (even taking into account the drop in referrals of cases from lower courts). The influence of the HRA becomes more apparent when we turn to the subject-matter of the petitions. The figures show that there has been a very substantial increase in the number of human rights petitions that are allowed. (The aggregate figures show this finding in a particularly striking way.) And it is not just that the House of Lords now receives many more petitions of this sort - although this is part of the picture. It is also a matter of deliberate selection, since our figures show that human rights petitions are more likely to be allowed than other categories of case (including those that fall within the 'rightsrelated' category). Post-HRA, then, the Law Lords seem keen to hear human rights cases. This may relate to the recognition of a responsibility to make sense of the new legal framework and to give lower courts guidance on how to interpret and apply it. But, whatever the motivation, it has important implications for the character of the court. The number of human rights cases being heard has shot up and the number of rights-related cases has remained fairly steady (even on our coding which, for reasons already given, tends to prioritise human rights cases). There is, then, no strong indication that there has been a great deal of repackaging of civil liberties (and similar) cases in terms of human rights. The net result is a court with a far more pronounced public law profile than it did pre-HRA - human rights and rights-related cases then amounted to around $20 \%$ of the petitions given leave; now they account for $40 \%$.

\section{HOUSE OF LORDS' JUDGMENTS}

The judgments of the House of Lords were examined next. A database of judgments handed down between 1 January 1994 and 31 December 2007 was compiled using the House of Lords' own website wherever possible. ${ }^{6}$ Unfortunately that website only contains judgments from mid-November 1996 so for the preceding period the Weekly Law Reports was used as the primary source. It

\footnotetext{
${ }^{56}$ Judgments are available at: http://www.parliament.uk/judicial_work/judicial_work5.cfm.
} 
is worth noting that the database records final judgments delivered rather than individual appeals disposed of - some cases are conjoined appeals in which only one judgment is delivered. For instance, only one judgment was given in Sheldrake $v$ DPP; Attorney-General's Reference (No. 4 of 2002) 57 $^{7}$ although that case counted in our leave to appeal figures as two separate appeals, one granted by the lower court and one granted by the House of Lords. The same coding categories (human rights; rights-related; refugee; and other) were deployed as before.

The analysis of the caseload of the House of Lords is reproduced in Table 4 and Table 5. Table 4 contains the total numbers of judgments delivered by the House of Lords in the period in question. The incidence of each type of case ('human rights', 'rights-related', 'refugee' and 'others') is given. For a clearer demonstration of the breakdown of the caseload, the absolute figures for each type of case are listed as a percentage of the total caseload in Table 5.

Table 4: Cases by Type

\begin{tabular}{c|cccc|c} 
Year & $\begin{array}{l}\text { Human } \\
\text { Rights } \\
\text { cases }\end{array}$ & $\begin{array}{l}\text { Rights- } \\
\text { related } \\
\text { cases }\end{array}$ & $\begin{array}{l}\text { Refugee } \\
\text { cases }\end{array}$ & $\begin{array}{l}\text { Other } \\
\text { cases }\end{array}$ & Total \\
\hline $\mathbf{1 9 9 4}$ & - & 7 & - & 37 & 44 \\
$\mathbf{1 9 9 5}$ & - & 5 & - & 42 & 47 \\
$\mathbf{1 9 9 6}$ & 2 & 3 & 2 & 34 & 41 \\
$\mathbf{1 9 9 7}$ & 1 & 7 & - & 49 & 57 \\
$\mathbf{1 9 9 8}$ & 1 & 7 & 1 & 43 & 52 \\
$\mathbf{1 9 9 9}$ & 6 & 9 & 2 & 35 & 52 \\
Up to October & 3 & 11 & 1 & 37 & 52 \\
$\mathbf{2 0 0 0}$ & & & & & \\
October to end & & & & & \\
of $\mathbf{2 0 0 0}$ & 2 & 2 & 1 & 12 & 17 \\
$\mathbf{2 0 0 1}$ & 14 & 6 & 1 & 49 & 70 \\
$\mathbf{2 0 0 2}$ & 14 & 3 & 3 & 30 & 50 \\
$\mathbf{2 0 0 3}$ & 21 & 5 & 2 & 41 & 69 \\
$\mathbf{2 0 0 4}$ & 20 & 6 & 1 & 29 & 56 \\
$\mathbf{2 0 0 5}$ & 30 & 9 & 3 & 32 & 74 \\
$\mathbf{2 0 0 6}$ & 13 & 7 & 2 & 35 & 57 \\
$\mathbf{2 0 0 7}$ & 18 & 3 & 2 & 35 & 58 \\
\hline
\end{tabular}

57 [2004] UKHL 43. 
$8 / 2009$

Table 5: Percentage of Total Caseload by Type

\begin{tabular}{c|cccc}
\hline Year & $\begin{array}{c}\text { Human } \\
\text { Rights cases } \\
(\%)\end{array}$ & $\begin{array}{c}\text { Rights- } \\
\text { related cases } \\
(\%)\end{array}$ & $\begin{array}{c}\text { Refugee } \\
\text { cases } \\
(\%)\end{array}$ & $\begin{array}{c}\text { Other cases } \\
\mathbf{( \% )}\end{array}$ \\
\hline $\mathbf{1 9 9 4}$ & - & 16 & - & 84 \\
$\mathbf{1 9 9 5}$ & - & 11 & - & 89 \\
$\mathbf{1 9 9 6}$ & 5 & 7 & 5 & 83 \\
$\mathbf{1 9 9 7}$ & 2 & 12 & - & 86 \\
$\mathbf{1 9 9 8}$ & 2 & 13 & 2 & 81 \\
$\mathbf{1 9 9 9}$ & 12 & 17 & 4 & 67 \\
Up to October & 6 & 21 & 2 & 84 \\
$\mathbf{2 0 0 0}$ & & & & \\
October to end & & 12 & 5 & 71 \\
of 2000 & 12 & 9 & 1 & 70 \\
$\mathbf{2 0 0 1}$ & 20 & 6 & 6 & 60 \\
$\mathbf{2 0 0 2}$ & 28 & 7 & 3 & 59 \\
$\mathbf{2 0 0 3}$ & 30 & 11 & 2 & 52 \\
$\mathbf{2 0 0 4}$ & 36 & 12 & 4 & 43 \\
$\mathbf{2 0 0 5}$ & 41 & 12 & 4 & 61 \\
$\mathbf{2 0 0 6}$ & 23 & 5 & 3 & 60 \\
$\mathbf{2 0 0 7}$ & 31 & & & \\
\hline
\end{tabular}

Depicting this data graphically makes it easier to identify caseload trends. Figure 3 shows the absolute numbers of cases heard by category.

Figure 3: House of Lords' Judgments by Category

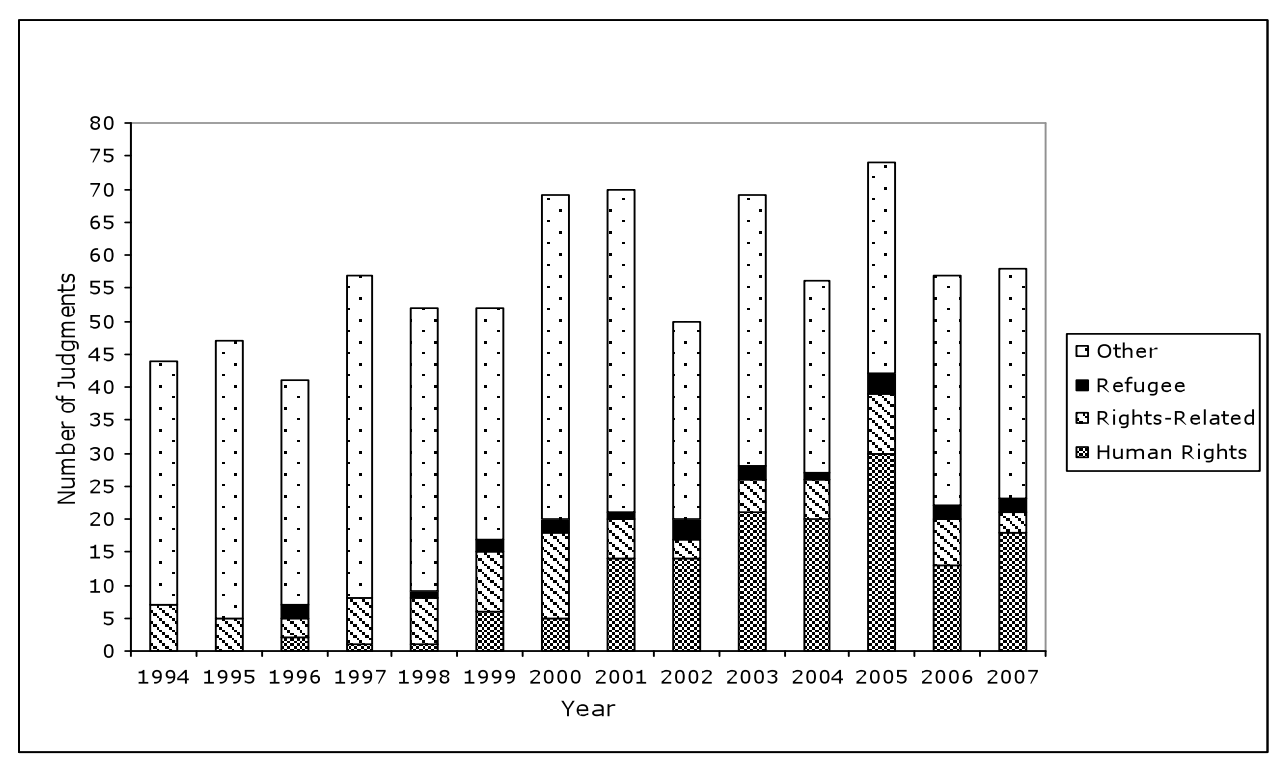


The data reveals three notable trends. First, there has been a noticeable increase in the number of judgments issued by the House of Lords during the period under study. This confirms the impression derived from the figures on leave petitions. The Law Lords dealt with between 41 and 57 cases per year in the first few years of the sample period; in the last few years, they have decided between 55 and 75 . There has been a significant rise in the total number of judgments delivered by the House of Lords after the HRA came into force in October 2000. It is difficult to specify precisely what influence the HRA is having here, as the number of cases was on the rise before the Act came into force. But the numbers do point to the HRA having at least some influence on the overall caseload. The Lords decided an average of 52 cases per year in the years before the HRA came into force; and an average of 63 cases per year thereafter.

Second, the figures show a substantial rise in human rights cases from an average of around 2 per year in the years before the HRA to an average of 17 per year in post-HRA years. Naturally, one would have expected the number of human rights cases to increase after the HRA came into force as a new ground for litigation was introduced. What is perhaps more striking is the proportion of the House of Lords' caseload that human rights cases now account for. As a percentage of total caseload, human rights cases increased from around $4 \%$ before the introduction of the Act to around 28\% thereafter. Although there is a significant downturn in the number of human rights cases decided in 2006 (less than half the number in 2005, a 'bumper' year for human rights litigation in the House of Lords), this does not appear to presage a general decline: there was an increase from 13 cases in 2006 to 18 cases in 2007.

Third, there was a slight downturn in the number of rights-related cases over the sample period. The Lords decided on average 8 rights-related cases per annum (14\% of their total caseload) before the HRA came into force; and around 6 per annum (9\% of the caseload) in the following years. This marginal decline does not seem to support the 'repackaging thesis' - that matters presented as rights-related cases pre-HRA have been turned into human rights cases post-HRA - although it is not possible given our methodology to say anything more definitive on this issue. As Figure 4 illustrates, the rights-related category remains pretty robust while the human rights category shows a sharp increase. If anything, the rapid expansion of human rights cases coincides more clearly with a moderate decrease in the number of 'other' cases dealt with combined with the overall increase in the total number of judgments already noted. 
Figure 4: House of Lords' Judgments by Category

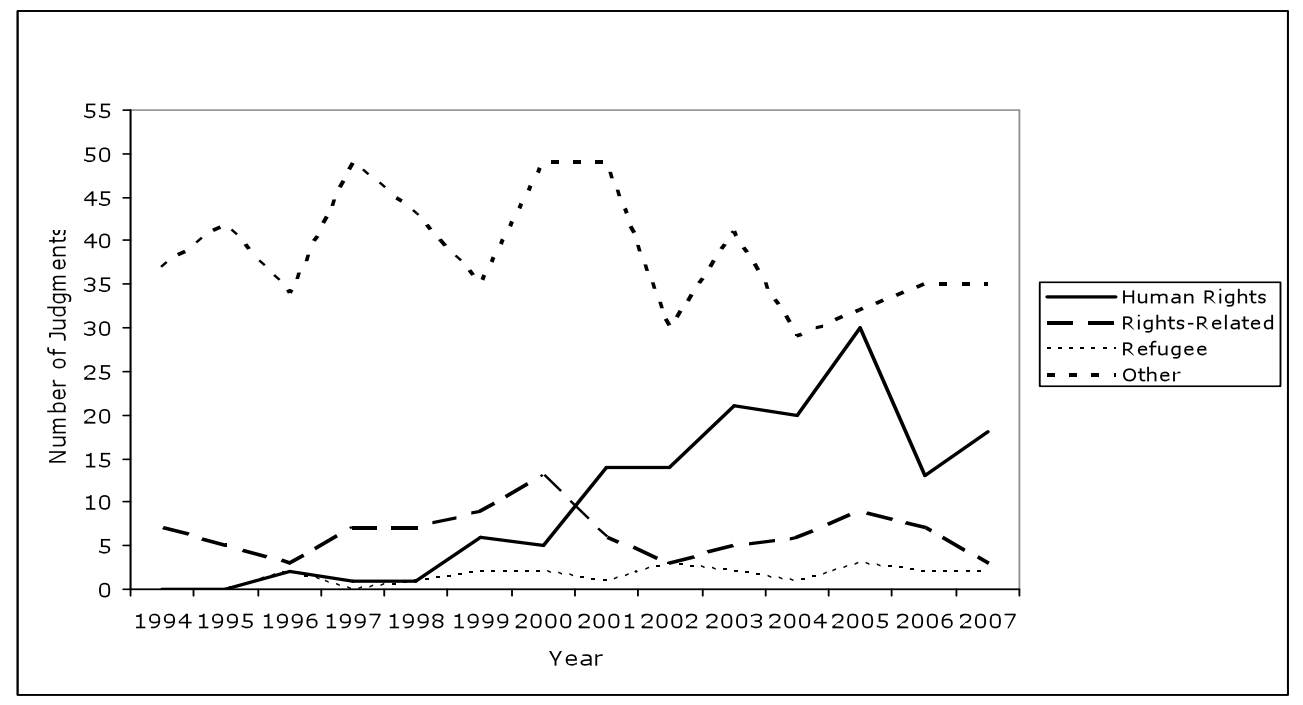

The incidence of 'refugee' (immigration and asylum) cases was also examined. This was done in part because previous empirical studies have shown that such cases often form a high proportion of (judicial review) cases, ${ }^{58}$ but also because this type of case receives considerable (and often critical) attention in the public discourse on the HRA. The figures show that over the period in question there were between 1 and 2 such cases per year (around 2\% of the total caseload). However, this does not include those cases that concerned refugee issues but which also referred to human rights and were as such coded as 'human rights' cases. There were 9 of these cases, ${ }^{59}$ all post-HRA. These account for around $7 \%$ of all 'human rights' cases heard since October 2000. Taking all refugee cases into account, refugee cases constitute around $4 \%$ of the post-HRA caseload compared with around $2 \%$ of the pre-HRA caseload. While this increase is not entirely insignificant, we can conclude that the very substantial rise in the incidence of human rights cases since the HRA - and the substantial rise in the overall caseload of the House of Lords during the same period - is not due to an increase in the numbers of cases concerning asylum and immigration matters.

\footnotetext{
58 See, e.g., M. Sunkin, 'What is Happening to Applications for Judicial Review?' (1987) 50 MLR 432; M. Sunkin, 'The Judicial Review Case-load 1987-1989' [1991] PL 490; and L. Bridges, G. Meszaros and M. Sunkin, Judicial Review in Perspective (London: Cavendish, 1995).

59 These cases are Secretary of State for the Home Department v AH (Sudan) and others [2007] UKHL 49; R (on the application of Bagdanavicius) v Secretary of State for the Home Department [2005] UKHL 38; N v Secretary of State for the Home Department [2005] UKHL 31; Limbuela, $n 55$ above; $R$ (on the application of Ullab) v Special Adjudicator, n 55 above; R (on the application of Razgar) v Secretary of State for the Home Department [2004] UKHL 27; $R$ (on the application of European Roma Rights Centre) v Immigration Officer at Prague Airport and another [2004] UKHL 55; Sepet and another v Secretary of State for the Home Department [2003] UKHL 15; R v Secretary of State for the Home Department, exp Saadi, n 55 above.
} 


\section{'WIN' RATES}

The success of 'human rights' and 'rights-related' cases in the House of Lords was examined next. The relevant judgments were coded as a 'win' or 'loss' depending on whether the human rights or rights-related claim met with success. Only where the substantive claim was upheld was the case coded as a 'win'. (Note that it is only possible to test human rights and rights-related cases in this way - and not for instance the cases that fell within the 'other' category - since what we are testing for is the success of human rights (and rights-related) arguments; not of individual applicants or appellants.) Where there were two 'rights' issues in a case in which the outcome differed for each, or conjoined appeals where the outcome in each appeal differed due to the particular facts of the case, ${ }^{60}$ the successful claim prevailed and the case was coded as a 'win'. In order to establish the 'win rate' of human rights and rights-related claims, the number of 'wins' in a particular category was divided by the total number of cases in that category. ${ }^{61}$ The findings are collated in Table 6 and Table 7.

Table 6: Win Rates in Human Rights Cases

\begin{tabular}{l|lll|c}
\hline Year & Wins & Losses & Total & $\begin{array}{c}\text { Success } \\
\text { Rate (\%) }\end{array}$ \\
\hline 1994 & - & - & - & - \\
1995 & - & - & - & - \\
1996 & 0 & 2 & 2 & 0 \\
1997 & 0 & 1 & 1 & 0 \\
1998 & 1 & 0 & 1 & 100 \\
1999 & 4 & 2 & 6 & 67 \\
Pre-October & 0 & 3 & 3 & 0 \\
2000 & & & & \\
Post- & 0 & 2 & 2 & 0 \\
October 2000 & & & & \\
2001 & 3 & 11 & 14 & 21 \\
2002 & 1 & 13 & 14 & 7 \\
2003 & 6 & 15 & 21 & 29 \\
2004 & 8 & 12 & 20 & 40 \\
2005 & 8 & 22 & 30 & 27 \\
2006 & 4 & 9 & 13 & 31 \\
2007 & 5 & 13 & 18 & 28 \\
\hline
\end{tabular}

${ }^{60}$ For example, $R$ (on the application of Clift) v Secretary of State for the Home Department [2006] UKHL 54 where the appeal on human rights grounds by Clift was dismissed but that made by the other two appellants in the case was allowed.

${ }^{61}$ Choudhry and Hunter n 24 above, deploy a broadly similar methodology in their study of Charter decision-making in the Canadian Supreme Court. 
Table 7: Win Rates in Rights-Related Cases

\begin{tabular}{l|lll|c}
\hline Year & Wins & Losses & Total & $\begin{array}{c}\text { Success } \\
\text { Rate (\%) }\end{array}$ \\
\hline 1994 & 3 & 4 & 7 & 43 \\
1995 & 4 & 1 & 5 & 80 \\
1996 & 1 & 2 & 3 & 33 \\
1997 & 2 & 5 & 7 & 29 \\
1998 & 1 & 6 & 7 & 14 \\
1999 & 5 & 4 & 9 & 56 \\
Pre-October & 3 & 8 & 11 & 27 \\
2000 & & & & \\
Post- & 1 & 1 & 2 & 50 \\
October 2000 & & & & \\
2001 & 3 & 3 & 6 & 50 \\
2002 & 2 & 1 & 3 & 67 \\
2003 & 2 & 3 & 5 & 40 \\
2004 & 4 & 2 & 6 & 67 \\
2005 & 4 & 5 & 9 & 44 \\
2006 & 3 & 4 & 7 & 43 \\
2007 & 2 & 1 & 3 & 67 \\
\hline
\end{tabular}

There are a number of points to be drawn from these data. Turning first to 'wins' in human rights cases, the figures show that there were relatively few human rights wins before the HRA came into force. Human rights claims won in only 5 out of a total of 13 pre-HRA cases (admittedly a small sample). Of 132 post-HRA cases involving human rights claims, 35 were successful. The win rate for human rights cases in post-HRA years ranges from $0 \%$ to around $40 \%$ in any given year (see Figure 5). In other words, human rights cases have not had a very high win rate in the House of Lords. On average, only one in three human rights claims is successful.

\section{Figure 5: Wins/ Losses in Human Rights Cases}

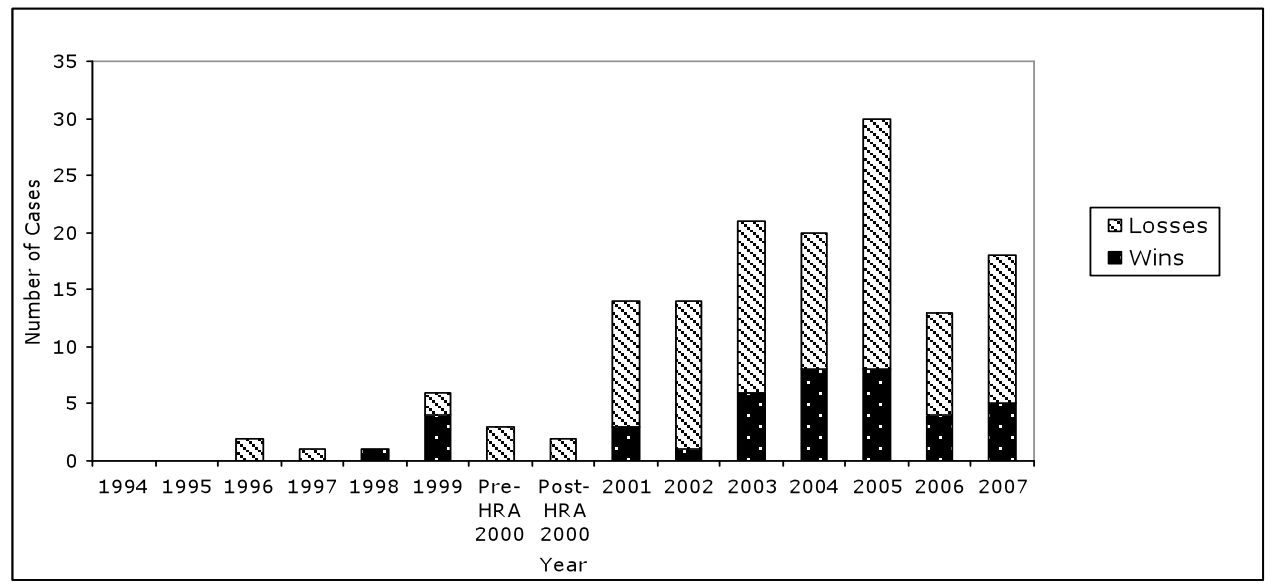


The low win rate for human rights cases is more striking when set against the figures for rights-related cases. There was little appreciable difference in the win rate of rights-related cases before and after the HRA came into force (see Figure O). Since October 2000, there have been fewer rights-related than human rights cases, but their win rate is substantially higher. Before the HRA came into force, rightsrelated claims won in 19 out of 49 cases. The average win rate for these claims was around $40 \%$ - the upper limit for the win rates of human rights claims. Post-HRA, the win rate in rights-related cases is still higher - 21 out of 41 claims (or 54\%) won. In other words, just over balf of rights-related claims brought before the House of Lords post-HRA have been successful.

Figure 6: Wins/ Losses in Rights-Related Cases

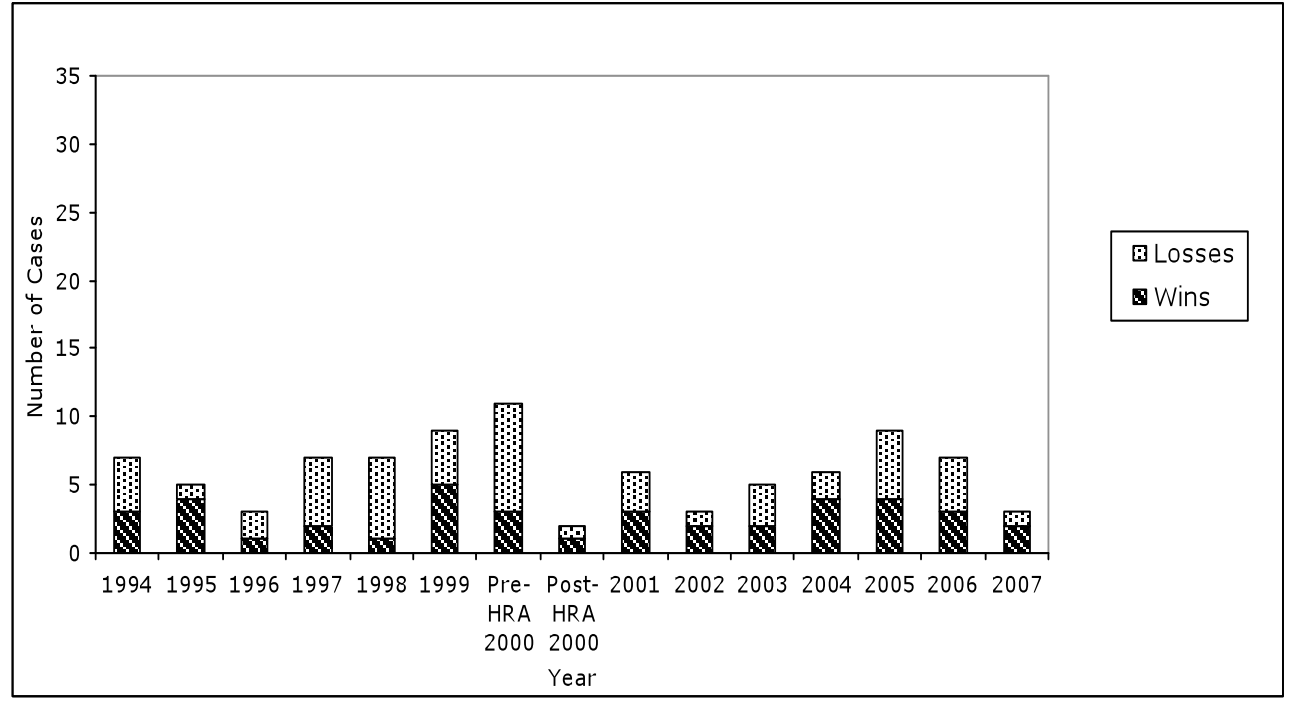

What is going on here? We noted in the previous section an increased willingness on the part of the Law Lords to hear human rights cases. But now we find that the win rate in such cases tends to be low - and certainly significantly lower than for rights-related cases. It seems that while the Lords are more willing to hear human rights cases than other types of case, they are more inclined to dismiss them than the other cases they hear. There are a number of possible explanations for this pattern. One (fairly prosaic) explanation might be that the Lords have not yet worked out a sufficiently rigorous mechanism by which weak human rights cases might be filtered out at the petition for leave stage - an understandable state of affairs given the novelty of much of the law being applied. Another explanation might be that while the Law Lords are interested in ruling on human rights claims, they are not so sympathetic to the substance of human rights claims. (They may even be taking up some of these cases in order to rule against them.) In either event, the lack of success of human rights cases at this level may have an impact 
upon the viability of the 'repackaging' thesis noted above, since it appears to undercut the incentive towards dressing up an argument in terms of human rights.

\section{The Privy CounciL}

The new UK Supreme Court will assume the powers of the current Appellate Committee of the House of Lords and the devolution jurisdiction of the Judicial Committee of the Privy Council. To complete this study, then, the Privy Council's decisions on devolution matters were examined. All three devolution statutes give the Privy Council appellate jurisdiction in devolution matters. One ground of appeal exists where a devolved authority is alleged to have acted in a manner inconsistent with the HRA. ${ }^{62} \mathrm{~A}$ database of Privy Council judgments and win rates in human rights cases was constructed in the same manner as for the House of Lords.

Figure 7: Privy Council Judgments

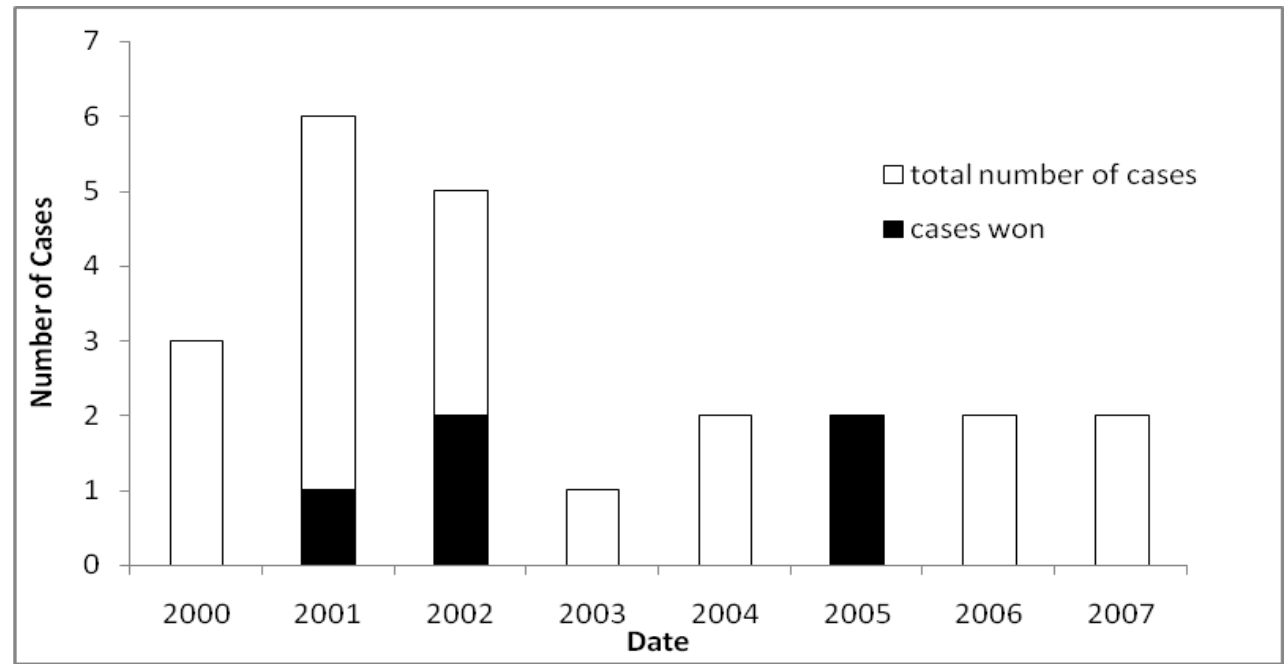

We found that all the devolution cases heard so far by the Privy Council have raised questions about human rights. Figure 7 shows the total number of devolution cases heard by the Privy Council in the survey period and the number of cases where the human rights argument won. Save for a relatively high incidence of cases in 2001 and 2002, there are generally only about 2 such cases per year. The win rate for human rights arguments in Privy Council decisions is very low: 5 out of 23 cases - a win rate of around $22 \%$. Although the small sample size makes the drawing of meaningful comparisons problematic, this figure compares unfavourably with the (in any case low) win rate of human rights cases decided by the House of Lords.

62 Scotland Act 1998 ss. 29(2)(d), 32, 33, 103 and Schedule 6; Government of Wales Act 2006 ss. 81, 94, 96 and 99; Northern Ireland Act 1998 ss. 11, 82. 


\section{FINDINGS AND CONCLUSIONS}

Care is needed when drawing conclusions from studies of this sort. Statistical analyses, revealing though they can be, often work best as platforms from which other studies can build. The general limitations of the method are compounded here by the fact that the present study relates only to the House of Lords, which means that it would be wrong to use these results as a basis from which to extrapolate freely about the impact of the HRA. The study's findings speak directly to trends within the House of Lords; they offer at best only indirect evidence for the impact of the HRA on the courts more generally.

These caveats notwithstanding, the study gives rise to a number of important findings. The analysis of petitions for leave to appeal from the sample period (1 January 1994 to 31 December 2007) shows that the House of Lords has become a steadily busier court. The HRA may have had some impact on this trend, since the Lords have shown themselves particularly willing to grant leave to human rights cases since the Act came into force. Not only has there been a substantial postHRA increase in petitions that raise human rights arguments; but the success rate of such petitions has also been high - substantially higher indeed than for other categories of case (including rights-related cases). This last finding indicates deliberate selection - the Lords seem keen to hear human rights cases.

The analysis of House of Lords' judgments also produced interesting results. It revealed, predictably enough, a very significant post-HRA increase in the incidence of human rights cases. (There is little indication, incidentally, that this process is about to be reversed. The 'teething process thesis' - which would predict that, after a period of activity during which the boundaries of the HRA were tested, the number of human rights claims should decline - is not supported by the evidence.) We also discovered, somewhat less predictably, that there had been no corresponding drop in the numbers of rights-related cases. This finding speaks against strong versions of the 'repackaging thesis' which predicts that many cases previously argued in terms of civil liberties (or similar) would be argued as human rights cases after the HRA came into force. ${ }^{63}$ The analysis does not indicate such a wholesale translation of old-style, common law grounds into the language of human rights, but rather the co-existence of both types of argument.

Asylum and immigration cases tend to receive much attention in the public debate on the HRA. A poll conducted for the Ministry of Justice found that $43 \%$ of the public believe that 'too many people (mostly asylum seekers and other 'foreigners') take advantage of the Human Rights Act'. ${ }^{64}$ The evidence indicates that at least in respect of the decision-making of the UK's highest court this perception is largely ungrounded. Only 9 of 132 post-HRA human rights cases

\footnotetext{
${ }_{63}$ Particularly as 'the courts must, so far as possible, declare the common law in a way compatible with Convention rights, just as they must, so far as is possible, interpret and give effect to legislation in that way', Lord Lester and K. Beattie 'Human Rights and the British Constitution' in J. Jowell and D. Oliver, The Changing Constitution, 5th edn (Oxford: Oxford University Press, 2007) 59, 76.

${ }^{64}$ Ministry of Justice, 'Human Rights Insight Project', Ministry of Justice Research Series 1/08, January 2008 at $8-9$.
} 
and only $4 \%$ of the total caseload of the House of Lords since October 2000 have involved these issues.

A more interesting feature of the statistics on judgments is the low win rate for human rights cases. Only one in three of these cases win in the House of Lords. This win rate is significantly lower than that of rights-related cases (about one in two). This finding complicates the picture derived from the analysis of the leave petitions, where human rights tended to be more rather than less successful relative to other types of case. One reason for this pattern might be that the Law Lords have yet to identify a suitable filtering mechanism to deal with this new body of law. A more likely explanation is that while the Lords may be keen on hearing human rights cases, they are not particularly sympathetic in general to human rights claims. The hovering presence of the European Court of Human Rights may also be having an impact on case selection. The Lords may be opting to deal with human rights cases 'in house' wherever possible, in part so that they can show in future challenges before the Strasbourg Court that human rights cases have been subject to intelligent analysis at the highest domestic level.

The evidence also speaks to the changing nature of the House of Lords. The data on leave petitions paint a picture of a busier court, more inclined to devote attention to the public law dimensions of its work. This impression is largely confirmed by the figures on actual decisions, which show that the House of Lords is now much more active on this front than it was before the HRA came into operation. If we combine human rights with rights-related and 'refugee' cases, public law issues (broadly defined) may be said to constitute some $42 \%$ of the caseload of the House of Lords, compared with $17 \%$ in the years before the Act came into force. This amounts to a profound shift in the practice of the court. Public law issues, it would appear, have moved from the periphery to the centre of the business of our highest court. Time will tell whether this trend will continue once the House of Lords has become the Supreme Court. 